\title{
PENGARUH PENYULUHAN GIZI TERHADAP PENGETAHUAN DAN SIKAP IBU DALAM PEMBERIAN MAKANAN PENDAMPING ASI DI KECAMATAN MATAN HILIR UTARA KABUPATEN KETAPANG TAHUN 2020
}

\section{Windiyati ${ }^{1}$, Sadriatanur ${ }^{2}$}

\author{
Akademi Kebidanan Panca Bhakti Pontianak \\ Email Korespondensi: akbidpbpontianak@gmail.com
}

\begin{abstract}
Abstrak
Masalah Gizi adalah masalah kesehatan masyarakat yang penanggulangannnya tidak dapat dilakukan dengan pendekatan medis dan pelayanan kesehatan saja juga menyangkut aspek pengetahuan dan perilaku yang kurang mendukung pola hidup sehat. Tujuan dalam penelitian adalah untuk mengetahui pengaruh penyuluhan gizi terhadap pengetahuan dan sikap ibu dalam pemberian makanan pendamping ASI di Kecamatan Matan Hilir Utara Kabupaten Ketapang Tahun 2020. Jenis penelitian ini adalah quasi eksperimental dimana bentuk desain yang dipakai adalah one group pretest-postest desain untuk mengetahui pengaruh antara penyuluhan gizi terhadap pengetahuan dan sikap ibu dalam pemberian makanan pendamping ASI. Hasil uji statistik Paired Sample T-Test diperoleh nilai $\mathrm{p}=0,0001(\mathrm{p}<0,05)$ yang artinya Ho ditolak (Ha diterima), jadi dapat disimpulkan ada pengaruh penyuluhan gizi terhadap pengetahuan ibu dalam pemberian makanan pendamping ASI .Dan dapat disimpulkan bahwa Ada pengaruh penyuluhan gizi terhadap pengetahuan ibu dalam pemberian makanan pendamping ASI di Kecamatan Matan Hilir Utara Kabupaten Ketapang Tahun 2020 ( $p$ value = 0,0001 $\mathrm{t}$ hitung $=13,051)$ dan ada pengaruh penyuluhan gizi terhadap sikap ibu dalam pemberian makanan pendamping ASI di Kecamatan Matan Hilir Utara Kabupaten Ketapang Tahun 2010 (p value = 0,0001 thitung = 4,893). Diperlukan kebijakan untuk meningkatkan penyuluhan kepada masyarakat tentang pemberian MPASI kepada ibu-ibu yang mempunyai bayi agar dapat meningkatkan pengetahuan, merubah sikap dan perilaku mengenai pemberian MP-ASI.
\end{abstract}

Kata kunci: Pengaruh, Pengetahuan, Sikap, MP-ASI.

\begin{abstract}
Nutritional problems are public health that can not be handled by a medical approach and health services alone also involve aspects of knowledge and behavior that do not support a healthy lifestyle. The purpose of this study was to determine the effect of nutrition counseling on the knowledge and attitudes of mothers in providing complementary feeding to breastfeeding in Matan Hilir Utara District, Ketapang Regency in 2020. This type of research is a quasi-experimental in which the form of design used is one group pretest-posttest design to determine the effect of nutritional education on knowledge and attitudes of mothers in complementary feeding. The results of the Paired Sample T-Test statistical test obtained $p$ value $=0.0001(p<0.05)$, which means that $\mathrm{Ho}$ is rejected (Ha is accepted), so it can be concluded that there is an effect of nutrition education on maternal knowledge in complementary feeding. And it can be concluded that There was an effect of nutritional counseling on maternal knowledge in complementary feeding in Matan Hilir Utara District, Ketapang Regency, in 2020 ( $\mathrm{p}$ value $=0.0001 \mathrm{t}$ count $=13.051$ ) and there was an effect of nutrition counseling on maternal attitudes in complementary feeding in Matan Hilir District. Utara, Ketapang Regency in 2010 (p value $=0.0001 \mathrm{t}$ count $=4.893$ ). A policy is needed to increase outreach to the community about giving complementary foods to mothers who have babies in order to increase knowledge, change attitudes and behavior regarding giving complementary foods Breast milk.
\end{abstract}

Keywords: Influence, Knowledge, Attitude, Food's Substitute for Breast Milk

\section{Pendahuluan}

Gizi memegang peranan penting dalam siklus hidup manusia. Kekurangan gizi pada

\footnotetext{
${ }^{1}$ Dosen Akademi Kebidanan Panca Bhakti Pontianak

${ }^{2}$ Mahasiswa Universitas Muhammadiyah Pontianak
}

ibu hamil dapat menyebabkan Bayi Berat Lahir Rendah (BBLR) dan dapat pula 
menyebabkan penurunan tingkat kecerdasan. Pada bayi dan anak, kekurangan gizi akan menimbulkan gangguan pertumbuhan dan perkembangan yang apabila tidak diatasi secara dini dapat berlanjut hingga dewasa.

Untuk mencapai tumbuh kembang yang optimal WHO (World Health Organitation) merekomendasikan empat hal penting yang harus dilakukan yaitu; pertama, memberikan air susu ibu kepada bayi segera dalam waktu 30 menit setelah bayi lahir, kedua, memberikan hanya air susu ibu (ASI) saja atau pemberian ASI secara eksklusif sejak lahir sampai bayi berusia 6 bulan, ketiga, memberikan makanan pendamping air susu ibu (MP-ASI) sejak bayi berusia 6 bulan sampai 24 bulan, dan keempat meneruskan pemberian ASI sampai anak berusia 24 bulan atau lebih. Rekomendasi tersebut menekankan, secara sosial budaya MP-ASI hendaknya dibuat dari bahan pangan yang murah dan mudah diperoleh di daerah setempat (indigenous food). Perbaikan gizi yang dilakukan Indonesia diharapkan dapat menurunkan masalah gizi kurang dari 27,3\% tahun 2013 menjadi $20 \%$ pada tahun 2019, dan masalah gizi buruk dari 8,0\% tahun 2013 menjadi $5 \%$ pada tahun 2019 (Depkes RI, 2016). Salah satu masalah kesehatan adalah Kesehatan bayi dan Balita.

Paradigma sehat merupakan cara pandang, pola pikir, atau pola pembangunan kesehatan yang bersifat holistik, yang dipengaruhi oleh berbagai faktor yang bersifat lintas sektor dan diarahkan pada pendekatan, peningkatan, pemeliharaan dan perlindungan kesehatan, bukan hanya penyembuhan orang sakit atau pemulihan kesehatan. Salah satu wujud paradigma sehat adalah promosi kesehatan (Depkes RI, 2012).

Usia 0-24 bulan merupakan masa pertumbuhan dan perkembangan yang pesat, sehingga sering diistilahkan sebagai periode emas sekaligus periode kritis. Periode emas dapat diwujudkan apabila pada masa ini bayi dan anak memperoleh asupan gizi yang sesuai untuk tumbuh kembang yang optimal. Sebaliknya apabila bayi dan anak pada masa ini tidak memperoleh makanan sesuai kebutuhan gizinya, maka periode emas akan berubah menjadi periode kritis yang akan mengganggu tumbuh kembang bayi dan anak, baik pada saat ini maupun masa selanjutnya (Depkes RI, 2016).

Beberapa hasil penelitian menyatakan bahwa keadaan kurang gizi pada bayi dan anak disebabkan karena kebiasaan pemberian makanan pendamping ASI yang tidak tepat. Ketidaktahuan tentang cara pemberian makanan pada bayi dan anak serta adanya kebiasaan yang merugikan kesehatan, menjadi penyebab utama terjadinya masalah gizi kurang pada anak, khususnya pada anak di bawah umur 2 tahun. Untuk mengatasi masalah tersebut di atas, dilakukan sejumlah kegiatan Keluarga Sadar Gizi (Kadarzi). Melalui penerapan perilaku Kadarzi, keluarga didorong untuk memberikan ASI Eksklusif pada bayi sejak lahir sampai berusia 6 bulan dan memberikan MP-ASI yang cukup serta bermutu kepada bayi dan anak usia 6-24 
bulan. Untuk mewujudkan program ini secara optimal maka perlu kerja sama yang profesional antara petugas kesehatan di lapangan (dokter/bidan) dan petugas kesehatan lain. (Depkes RI, 2016).

Dalam periode pemberian makanan pendamping ASI, bayi sepenuhnya tergantung pada perawatan dan pemberian makan oleh ibunya. Oleh karena itu pengatahuan dan sikap ibu sangat berperan, sebab pengetahuan tentang pemberian makanan pendamping ASI dan sikap ibu yang baik terhadap pemberian makanan pendamping ASI akan menyebabkan seseorang mampu menyusun menu yang baik untuk dikonsumsi oleh bayinya. Semakin baik pengetahuan gizi seseorang maka ia akan semakin memperhitungkan jenis dan jumlah makanan yang diperoleh untuk di konsumsi (Ahmad, 2010).

Berdasarkan laporan Program Gizi Dinas Kesehatan Propinsi Kalimantan Barat Tahun 2019, bahwa pencapaian ASI Eklusif $33,27 \%$ dari hasil pencapaian tersebut tenyata sebagian besar bayi di bawah usia 6 bulan sudah mendapat makanan pendamping ASI secara dini (Profil Dinkes Propinsi Kalbar, 2019). Di Kecamatan Matan Hilir Utara menunjukkan bahwa cakupan ASI Eksklusif $0 \%$ dengan demikian anak mendapat MP-ASI secara dini dengan 2,74\% anak yang menderita gizi buruk (Laporan program gizi Dinas Kesehatan Kabupaten Ketapang Tahun 2019).

\section{Metode}

Jenis penelitian ini adalah quasi eksperimental dimana bentuk desain yang dipakai adalah one group pretest-postest desain untuk mengetahui pengaruh antara penyuluhan gizi terhadap pengetahuan dan sikap ibu dalam pemberian makanan pendamping ASI di Kecamatan Matan Hilir Utara Kabupaten Ketapang Tahun 2020. Dimana dalam rancangan ini tidak ada kelompok pembanding (kontrol) tetapi dilakukan observasi pertama (pre-test) yang memungkinkan peneliti dapat menguji perubahan yang terjadi setelah adanya perlakuan.

Populasi dalam penelitian ini adalah ibu yang mempunyai bayi usia 6-11 bulan yang berada di Kecamatan Matan Hilir Utara Kabupaten Ketapang tahun 2010 dengan jumlah 45 orang.Sampel diambil dengan metode Probabiliy Sampling. Data dianalisis dengan menggunakan uji statistik yaitu uji paired sample t-test untuk melihat perbedaan sebelum dan sesudah perlakuan.

\section{Hasil}

Tabel 1 Hasil Analisa

\begin{tabular}{lccccccc}
\hline \multirow{2}{*}{ Variabel } & \multicolumn{2}{c}{ Mean } & \multicolumn{2}{c}{ SD } & \multicolumn{2}{c}{ SE } & \multirow{2}{*}{ P-Value } \\
\cline { 2 - 7 } & Pre-test & Post-test & Pre-test & Post-test & Pre-test & Post-tes & \\
\hline Pengetahuan & 8,02 & 9,84 & 2,331 & 2,195 & 0,347 & 0,327 & 0,0001 \\
Sikap & 4,84 & 8,84 & 1,623 & 1,906 & 0,242 & 0,284 & 0,0001 \\
\hline
\end{tabular}


Berdasarkan tabel di atas, diketahui bahwa rata-rata pengetahuan ibu sebelum diberikan penyuluhan yaitu 8,02 dengan standar deviasi 2,331 dan rata-rata pengetahuan ibu sesudah diberikan penyuluhan yaitu 9,84 dengan standar deviasi 2,195 . sedangkan nilai mean perbedaan pengetahuan ibu sebelum dan sesudah diberikan penyuluhan adalah 1,822 dengan standar deviasi 2,498 dan t hitung 4,893.

Hasil uji statistik Paired Sample T-Test diperoleh nilai $p=0,0001(\mathrm{p}<0,05)$ yang artinya Ho ditolak (Ha diterima), jadi dapat disimpulkan ada pengaruh penyuluhan gizi terhadap pengetahuan ibu dalam pemberian makanan pendamping ASI di Kecamatan Matan Hilir Utara Kabupaten Ketapang Tahun 2020.

Pada variabel Sikap, diketahui bahwa rata-rata sikap ibu sebelum diberikan penyuluhan yaitu 4,84 dengan standar deviasi 1,623 dan rata-rata sikap ibu sesudah diberikan penyuluhan yaitu 8,84 dengan standar deviasi 1,906 , sedangkan nilai mean perbedaan sikap ibu sebelum dan sesudah diberikan penyuluhan adalah 4,000 dengan standar deviasi 2,056 dan thitung 13,051.

Hasil uji statistik Paired Sample T-Test diperoleh nilai $p=0,0001(\mathrm{p}<0,05)$ yang artinya Ho ditolak (Ha diterima), jadi dapat disimpulkan ada pengaruh penyuluhan gizi terhadap sikap ibu dalam pemberian makanan pendamping ASI di Kecamatan Matan Hilir Utara Kabupaten Ketapang Tahun 2020.

Pengaruh penyuluhan gizi terhadap pengetahuan ibu dalam pemberian makanan pendamping ASI di Kecamatan Matan Hilir Utara Kabupaten Ketapang

Hasil uji statistik Paired Sample T-Test diperoleh nilai $p$ value $=0,0001(\mathrm{p}<0,05)$ yang artinya Ho ditolak (Ha diterima), maka dapat disimpulkan ada pengaruh penyuluhan gizi terhadap pengetahuan ibu dalam pemberian makanan pendamping ASI di Kecamatan Matan Hilir Utara Kabupaten Ketapang Tahun 2020.

Berdasarkan hasil penelitian, ada pengaruh yang signifikan terhadap pengetahuan ibu sebelum dan sesudah diberikan penyuluhan maka terlihat dari nilai jawaban ibu, sebelum diberikan penyuluhan pengetahuan skor rata-rata nilai pengetahuan ibu 8,02, dan sesudah diberikan penyuluhan terjadi peningkatan skor rata-rata menjadi 9,84. Dari aspek jumlah ibu sebelum diberikan penyuluhan terdapat $60,0 \% \mathrm{ibu}$ dengan katagori pengetahuan kurang, dan sesudah diberikan penyuluhan terjadi peningkatan jumlah ibu dengan katagori pengetahuan baik terdapat 73,3\% Artinya sesudah diberikan penyuluhan tentang pemberian makanan pendamping ASI, jumlah ibu dengan katagori pengetahuan baik meningkat sebesar 13,3\%.

Hasil pengetahuan ibu sebelum intervensi dari item pertanyaan pengetahuan ibu dalam pemberian makanan pendamping ASI ternyata sebagian besar dari responden mempunyai pengetahuan kurang tentang Manfaat pemberian Makanan Pendamping ASI sebanyak 29 orang (64\%) dan sebanyak 27 orang $(60 \%)$ pengetahuannya kurang 
tentang ASI Eksklusif, sesudah dilakukun intervensi terjadi peningkatan pengetahuan ibu dan masih terdapat sedikit dari responden yang kurang pengetahuannya tentang Susu Kolostrum setelah dilakukan intervensi sebesar 14 orang $(31,1 \%)$

Menurut Notoatmodjo (2013), bahwa pengetahuan merupakan hasil dari tahu, tahu diartikan mengingat materi yang telah dipelajari sebelumnya. Termasuk ke dalam pengetahuan tingkat ini adalah mengingat kembali sesuatu yang spesifik dari seluruh badan yang dipelajari atau rancangan yang diterima.

Menurut Maulana (2012) faktor-faktor yang sangat mempengaruhi penyuluhan kesehatan adalah dalam aspek pemilihan metode, alat bantu/peraga, dan jumlah kelompok sasaran. Artinya untuk mendapatkan hasil dari penyuluhan dengan maksimal ketiga faktor tersebut sangat mempengaruhi. Penyuluhan secara umum merupakan proses pemberian bantuan kepada inividu yang dilakukan secara berkesinambungan supaya individu dapat memahami dan menolong dirinya sendiri, dimana tujuan dari penyuluhan adalah tercapainya perubahan perilaku individu, keluarga dan masyarakat agar dapat berperan aktif dalam upaya peningkatan derajat kesehatan yang optimal.

Hasil penelitian ini sejalan dengan penelitian yang dilakukan oleh Martini (2017), mengatakan sebagian besar ibu memiliki pengetahuan yang cukup 50,7\% terhadap pemberian MP-ASI dan terdapat hubungan antara tingkat pengetahuan dalam pemberian MP ASI dengan pelaksanaan pemberian MP ASI yang tepat waktu dan demikian juga penelitian yang dilakukan oleh Yulianti (2012), menyatakan tingkat pengetahuan ibu tentang makanan pendamping ASI termasuk dalam katagori cukup $(68,8 \%)$ hal ini menunjukkan ada hubungan yang signifikan antara tingkat pengetahuan ibu tentang makanan pendamping ASI dengan perubahan berat badan balita.

Dapat disimpulkan bahwa hubungan antara pengetahuan dengan perilaku ibu dalam pemberian makanan pendamping ASI ternyata mereka yang pengetahuannya kurang cenderung memberikan makanan pendamping ASI secara dini lebih besar dibanding yang memiliki pengetahuan baik. Sejalan dengan pendapat ini bahwa pengetahuan merupakan hasil dari tahu dan terjadi setelah orang melakukan penginderaan terhadap suatu obyek tertentu, dengan demikian responden dapat mengetahui pemberian MP-ASI secara benar.

Oleh karena itu perlu meningkatkan informasi serta meningkatkan frekuensi penyuluhan kepada ibu-ibu yang mempunyai bayi agar dapat meningkatkan pengetahuan, sikap dan perilaku mengenai pemberian MPASI. Dalam menyampaikan informasi ini dapat dilakukan kerja sama dengan klinik swasta, kader kesehatan dan tokoh masyarakat.

Pengaruh penyuluhan gizi terhadap sikap ibu dalam pemberian makanan 
pendamping ASI di Kecamatan Matan

\section{Hilir Utara Kabupaten Ketapang}

Berdasarkan dari hasil analisa uji statistik Paired Sample T-Test diperoleh nilai $p$ value $=0,0001(\mathrm{p}<0,05)$ yang artinya Ho ditolak (Ha diterima), jadi dapat disimpulkan ada pengaruh penyuluhan gizi terhadap sikap ibu dalam pemberian makanan pendamping ASI di Kecamatan Matan Hilir Utara Kabupaten Ketapang Tahun 2020.

Berdasarkan hasil penelitian diperoleh perbedaan sikap ibu secara signifikan anatara sebelum dan sesudah diberikan penyuluhan maka terlihat dari nilai jawaban ibu, sebelum diberikan penyuluhan skor rata-rata nilai sikap ibu tidak mendukung 4,84, dan sesudah diberikan penyuluhan terjadi peningkatan skor rata-rata menjadi 8,84. Dari aspek jumlah ibu sebelum diberikan penyuluhan sebanyak $55,1 \%$ dengan katagori sikap ibu tidak mendukung, dan sesudah diberikan penyuluhan terjadi peningkatan jumlah ibu dengan katagori sikap mendukung sebanyak 77,8\% Artinya sesudah diberikan penyuluhan tentang pemberian makanan pendamping ASI, jumlah ibu dengan katagori sikap mendukung meningkat sebesar $22,7 \%$.

Berdasarkan pernyataan sikap ibu sebelum dilakukan intervensi penyuluhan dalam memberikan makanan pendamping ASI hampir seluruh responden tidak mendukung pernyataan apabila pemberian MP-ASI lebih cepat membahayakan kesehatan bayi sebanyak 40 orang $(88,8 \%)$, dan sesudah dilakukan intervensi ternyata pernyataan sikap ibu dalam memberikan makanan pendamping ASI sedikit dari responden yang tidak mendukung pernyataan berikan ASI dahulu baru MP-ASI agar ASI dimanfaatkan seoptimal mungkin sebanyak 9 orang $(20 \%)$.

Secara umum sikap dapat di rumuskan sebagai kecendrungan berindak dari individu, berupa respon yang tertutup terhadap stimulus atau objek. (Sunaryo, 2014). Sikap belum merupakan suatu tindakan atau aktivitas, akan tetapi merupakan predisposisi tindakan suatu perilaku.

Dari hasil penelitian diperoleh bahwa rata-rata sikap ibu sebelum diberikan penyuluhan yaitu 4,84 dengan standar deviasi 1,623 sedangkan rata-rata sikap ibu sesudah diberikan penyuluhan yaitu 8,84 dengan standar deviasi 1,906. terlihat nilai mean perbedaan sikap ibu sebelum dan sesudah diberikan penyuluhan adalah 4,000 dengan standar deviasi 2,056 dan t hitung 13,051. Hal ini disebabkan sikap ibu yang tidak mendukung justru mau menerima pemberian makanan pendamping ASI dikarenakan agar ada penambahan gizi pada anak.

Bertambah umur bayi bertambah pula kebutuhan gizinya. Ketika bayi memasuki usia 6 bulan ke atas, beberapa elemen nutrisi seperti karbohidrat, protein dan beberapa vitamin dan mineral yang terkandung dalam ASI atau susu formula tidak lagi mencukupi. Sebab itu sejak usia 6 bulan, kepada bayi selain ASI mulai diberi makanan pendamping ASI (MP-ASI ). Agar kebutuhan gizi bayi/anak terpenuhi.

Dalam pemberian MP-ASI perlu 
diperhatikan waktu pemberian MP-ASI, frekuensi porsi, pemilihan bahan makanan, cara pembuatan dan cara pemberiannya. Disamping itu perlu pula diperhatikan pemberian makanan pada waktu anak sakit dan bila ibu bekerja di luar rumah. Pemberian MP-ASI yang tepat diharapkan tidak hanya dapat memenuhi kebutuhan gizi bayi, namun juga merangsang keterampilan makan dan merangsang rasa percaya diri (Kemenkes RI, 2013).

Hasil penelitian ini sejalan dengan penelitian yang dilakukan oleh Heni (2012), menunjukkan dari 43 responden, 34 responden $(79,1 \%)$ yang tidak pernah mendengar kata ASI eksklusif dan 9 responden $(20,9 \%)$ yang pernah mendengar. Masih banyak responden yang memberikan makanan pendamping ASI kepada bayi yang berumur 1 bulan.

Definisi sikap menurut Thurstone (2010) yang dikutip Azwar (2013), adalah derajat efek positif atau afek negatif yang dikaitkan dengan suatu obyek psikologis. Sikap adalah keadaan mental dan syaraf dari kesiapan, yang diatur melalui pengalaman yang memberikan pengaruh dinamik atau terarah terhadap respon individu pada semua obyek dan situasi yang berkaitan dengannya. Dari sini sikap dapat digambarkan sebagai kecenderungan subyek merespon suka atau tidak suka terhadap suatu obyek. Dalam bahasan ini yang berperan sebagai subyek yaitu Ibu dan obyek yaitu pemberian Makanan Pendamping ASI kepada bayi.

Sikap ini ditunjukkan dalam berbagai kualitas dan intensitas yang berbeda dan bergerak secara kontinyu dari positif melalui areal netral ke arah negatif. Kualitas sikap digambarkan sebagai valensi positif menuju negatif, sebagai hasil penilaian terhadap obyek tertentu. Sedangkan intensitas sikap digambarkan dalam kedudukan ekstrim positif atau negatif. Kualitas dan intensitas sikap tersebut menunjukkkan suatu prosedur pengukuran yang menempatkan sikap seseorang dalam sesuatu dimensi evaluatif yang bipolar dari ekstrim positif menuju ekstrim negatif.

Menyimak uraian sikap di atas dapat dipahami bahwa sikap merupakan suatu bentuk evaluasi atau reaksi perasaan terhadap suatu obyek. Seseorang bersikap terhadap suatu obyek dapat diketahui dari evaluasi perasaannya terhadap obyek tersebut. Evaluasi perasaan ini dapat berupa perasaan senang-tidak senang, memihak-tidak memihak, favorit-tidak favorit, positifnegatif.

Walgito (2011), mengemukakan bahwa sikap adalah faktor yang ada dalam diri manusia yang dapat mendorong atau menimbulkan perilaku tertentu. Adapun ciriciri sikap yaitu: tidak dibawa sejak lahir, selalu berhubungan dengan obyek sikap, dapat tertuju pada satu obyek saja maupun tertuju pada sekumpulan obyek-obyek, dapat berlangsung lama atau sebentar, dan mengandung faktor perasaan dan motivasi.

Oleh karena itu diperlukan kebijakan untuk meningkatkan penyuluhan kepada masyarakat tentang pemberian MP-ASI 
kepada ibu yang mempunyai bayi agar dapat meningkatkan pengetahuan, merubah sikap dan perilaku mengenai pemberian MP-ASI. Dengan kerjasama lintas program dan lintas sektoral serta melibatkan kader kesehatan dan tokoh masyarakat. perlu melakukan promosi kesehatan secara masal, seperti membagikan leaflet, memasang poster dan memasang spanduk yang memuat pesan tentang MP-ASI. Kepada petugas gizi yang berhubungan langsung dalam memberikan pelayanan terhadap ibu dan anak untuk selalu melakukan bimbingan dan konseling tentang perilaku yang benar dalam pemberian MP-ASI kepada ibu hamil, ibu-ibu yang mempunyai bayi dan ceramah dan diskusi secara berkala di posyandu.

\section{Kesimpulan}

Berdasarkan hasil dan pembahasan, dapat ditarik beberapa kesimpulan sebagai berikut :

1. Sebagian besar ibu sebelum diberikan penyuluhan memiliki pengetahuan kurang yaitu 60,0\% dalam pemberian MP-ASI dan sesudah diberikan penyuluhan memiliki pengetahuan baik yaitu $73,3 \%$, maka terjadi peningkatan pengetahuan ibu baik setalah diberikan penyuluhan sebesar $13,3 \%$.

2. Sebagian dari ibu sebelum diberikan penyuluhan memiliki sikap tidak mendukung yaitu $51,1 \%$ dalam pemberian MP-ASI dan sesudah diberikan penyuluhan memiliki sikap yang mendukung yaitu $77,8 \%$, maka terjadi peningkatan sikap ibu yang mendukung pemberian MP-ASI setelah diberikan penyuluhan sebesar $22,7 \%$.

3. Ada pengaruh penyuluhan gizi terhadap pengetahuan ibu dalam pemberian makanan pendamping ASI di Kecamatan Matan Hilir Utara Kabupaten Ketapang Tahun $20210(p$ value $=0,0001$ thitung $=$ 13,051).

4. Ada pengaruh penyuluhan gizi terhadap sikap ibu dalam pemberian makanan pendamping ASI di Kecamatan Matan Hilir Utara Kabupaten Ketapang Tahun 2010 ( $p$ value $=0,0001$ thitung $=4,893)$.

Berdasarkan kesimpulan diatas, maka peneliti ingin menyampaikan beberapa hal kepada berbagai pihak, yaitu diperlukan kebijakan untuk meningkatkan penyuluhan kepada masyarakat tentang pemberian MPASI kepada ibu-ibu yang mempunyai bayi agar dapat meningkatkan pengetahuan, merubah sikap dan perilaku mengenai pemberian MP-ASI. Dengan kerjasama lintas program dan lintas sektor dengan melibatkan kader kesehatan dan tokoh masyarakat. Selain itu perlunya peningkatan pengetahuan ibu-ibu tentang bahaya dari pemberian makanan pendamping ASI (MP-ASI).

\section{Daftar Pustaka}

Ahmad, Djaeni S. 2010. Ilmu Gizi untuk Mahasiswa dan Profesi di Indonesia Jilid II. Jakarta: Dian Ratna

Azwar, S. 2013. Sikap Manusia: Teori dan Pengukurannya. Yogyakarta: Pustaka Pelajar

Depkes. 2012. Perilaku Hidup Bersih dan Sehat di Rumah Tangga. Jakarta: Departemen Kesehatan RI 
Depkes. 2016. Pedoman Umum Pemberian Makanan Pendamping ASI ( MP-ASI) Lokal. Jakarta: Departemen Kesehatan RI

Dinas Kesehatan Kabupaten Ketapang 2019. Laporan Program Perbaikan Gizi Dinas Kesehatan Tahun 2019. Ketapang

Dinas Kesehatan Provinsi Kalbar.2018. Profil Dinas Kesehatan Tahun 2009. KalBar.

Heni. 2012. Hubungan Terhadap Pemberian Makanan Pendamping ASI Pada Bayi Bogor Jawa Barat. Skripsi.(tidak dipublikasikan)

Kemenkes. 2013. Buku Panduan Kader Posyandu. Jakarta: Kemenkes RI

Maritini. 2017. Hubungan Tingkat Pengetahuan Ibu dengan Ketepatan Waktu Pemberian Makanan Pendamping ASI di Wilayah Kerja Puskesmas Tawangmangu Kabupaten Karang anyer.Skripsi.(tidak dipublikasikan)

Maulana, Heri. 2019. Promosi Kesehatan. Penerbit Buku Kedokteran .EGC. Jakarta

Notoatmodjo, Soekidjo, 2013. Pendidikan dan Prilaku Kesehatan. PT. Rineka Cipta

Sunaryo. 2014. Ilmu Gizi. Jakarta: Dian Rakyat

Walgito. 2011. Peranan Sikap Dalam Mengambil Suatu Keputusan. CV. Alfa Beta Bandung

Yulianti, Lia. 2012. Hubungan Tingkat Pengetahuan Ibu Tentang Makanan Pandamping ASI dengan Perubahan Berat Badan Balita Usia 6-24 Bulan di Posyandu Cempaka Tanjung Rasa Kidul Patok Beusi Subang Jawa Barat. Skripsi. (tidak dipublikasikan) 